\title{
A NEW PHRAGMIPEDIUM (ORCHIDACEAE) FROM COLOMBIA
}

\author{
Wesley E. Higgins ${ }^{1-3,5}$ \& Paula Viveros ${ }^{4}$ \\ ${ }^{1}$ Center for Tropical Plant Research and Conservation, Marie Selby Botanical Gardens \\ 811 South Palm Avenue, Sarasota, FL 34236-7726 U.S.A. \\ ${ }^{2}$ International Scientific Committee of Lankesteriana, Universidad de Costa Rica. \\ ${ }^{3}$ Research Associate, Centro de Investigación en Orquídeas de los Andes "Ángel Andreetta" \\ Universidad Alfredo Pérez Guerrero, Ecuador. \\ ${ }^{4}$ School of Forest Resources and Conservation, University of Florida, Gainesville, FL 32653, U.S.A. \\ ${ }^{5}$ Corresponding author: whiggins@selby.org
}

\begin{abstract}
Anew species from Colombia in Phragmipedium section Micropetalum is described: Phragmipedium manzurii.

Resumen. Se describe una nueva especie de Phragmipedium sección Micropetalum para Colombia: Phragmipedium manzuri.
\end{abstract}

Key words: Orchidaceae, Cypripedioideae, Phragmipedieae, Phragmipediinae, Phragmipedium, Micropetalum, Colombia, new species, taxonomy

Introduction. In April 2008 David Manzur sent photographs of a Phragmipedium for identification to the Orchid Identification Center. The images appeared distinctive from Phragmipedium schlimii thus necessitating examination of the specimen by a taxonomist. Since Manzur was unable to send a specimen due to governmental restrictions Paula Viveros traveled to Colombia to examine the plant. Viveros examined eight specimens and confirmed that they represented a new species.

David Manzur started collecting plants in Antioquia, Colombia, several years ago. At first he thought that they all corresponded to Phragmipedium schlimii, but he started noticing differences in floral structures and leaves that led him to suspect that they corresponded to different varieties or species. Consequently he started collecting phragmipediums from other regions in Colombia, growing them, and recording their variations. He keeps his living collections at his farm in Caldas, Colombia; the herbarium specimens are kept at Herbario Universidad de Caldas, FAUC.

\section{Taxonomic treatment}

Phragmipedium manzurii W.E. Higgins \& P. Viveros, sp. nov.

Type: Colombia. Santander: ex hort. D. A. Manzur. June 2008, D.A. Manzur 1501 (holotype: FAUC). FIG. 1-3.

Species haec Phragmipedium fischeri Braem \& Mohr et P. schlimii (Linden \& Rchb.f.) Rolfe similis, sed staminodio circulari breve emarginato viridiflavo differt, sepalis et petalisque subviridis, ellipticis; petalis complanatis subviolaceis, et labello albido intus violaceo notato, ad apicem inflato incurvato porcato differt.

Section Micropetalum (Hallier) Garay.

Plant caespitose, herbaceous, terrestrial. Leaves 6, basal distichous, blades linear, coriaceous, keeled beneath, acuminate, margin revolute, 29.5 to $36.6 \mathrm{~cm}$ long, 2.3 to $4 \mathrm{~cm}$ wide. Inflorescence erect, 12 to $27 \mathrm{~cm}$ tall. Ovary pubescent 4.8 to $5.8 \mathrm{~cm}$ long, subtended by an acute green floral bract. Flowers 3 successive, resupinate, $6 \times 5.2 \mathrm{~cm}$. Sepals yellow-green, elliptical, 


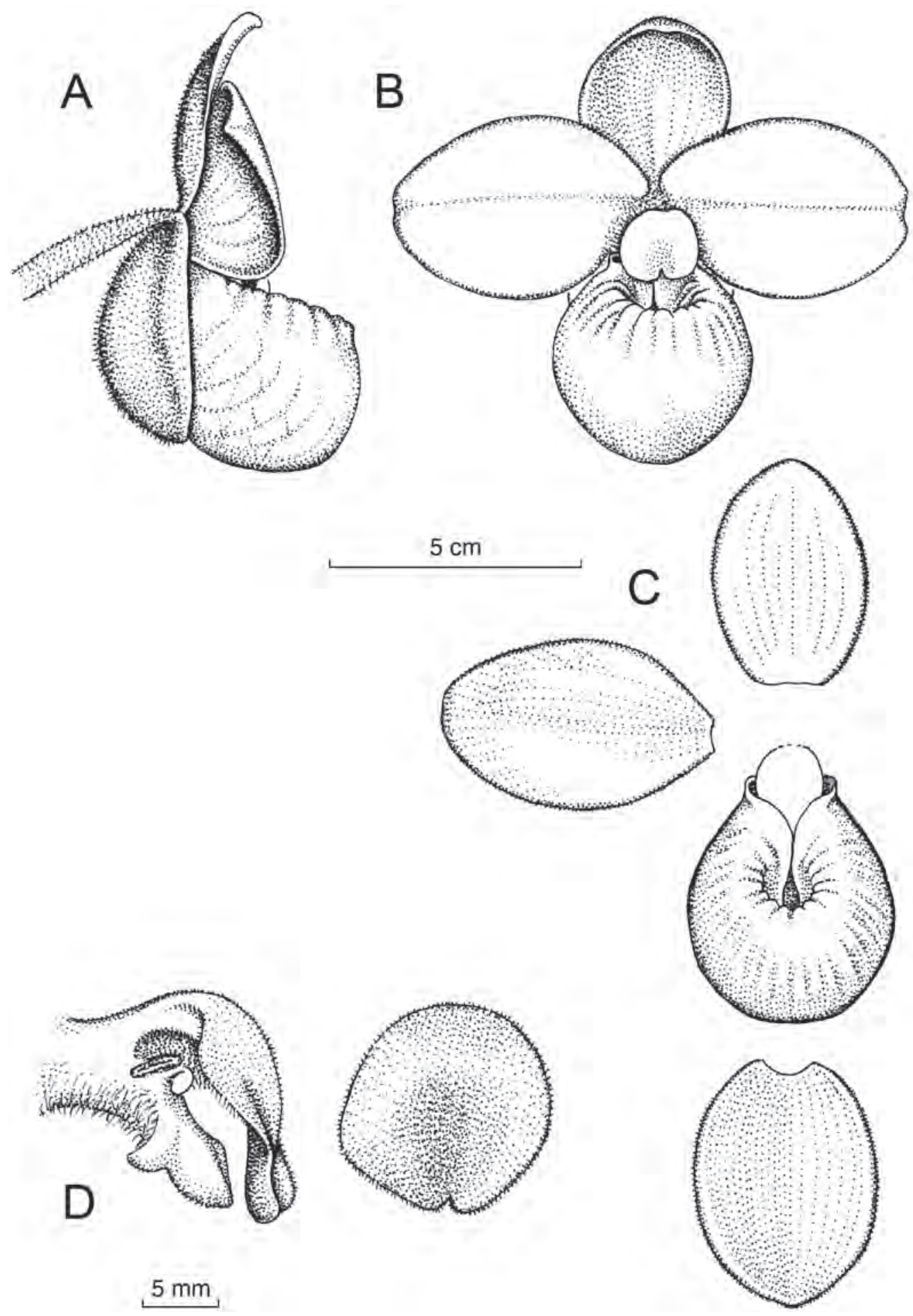

Figure 1. Phragmipedium manzurii W.E.Higgins \& P.Viveros. A. Flower, lateral view. B. Flower, frontal view. C. Dissected flower. D. Staminode, frontal and lateral view. Drawing by Stig Dalström, based on Manzur 1501 (FAUC). 

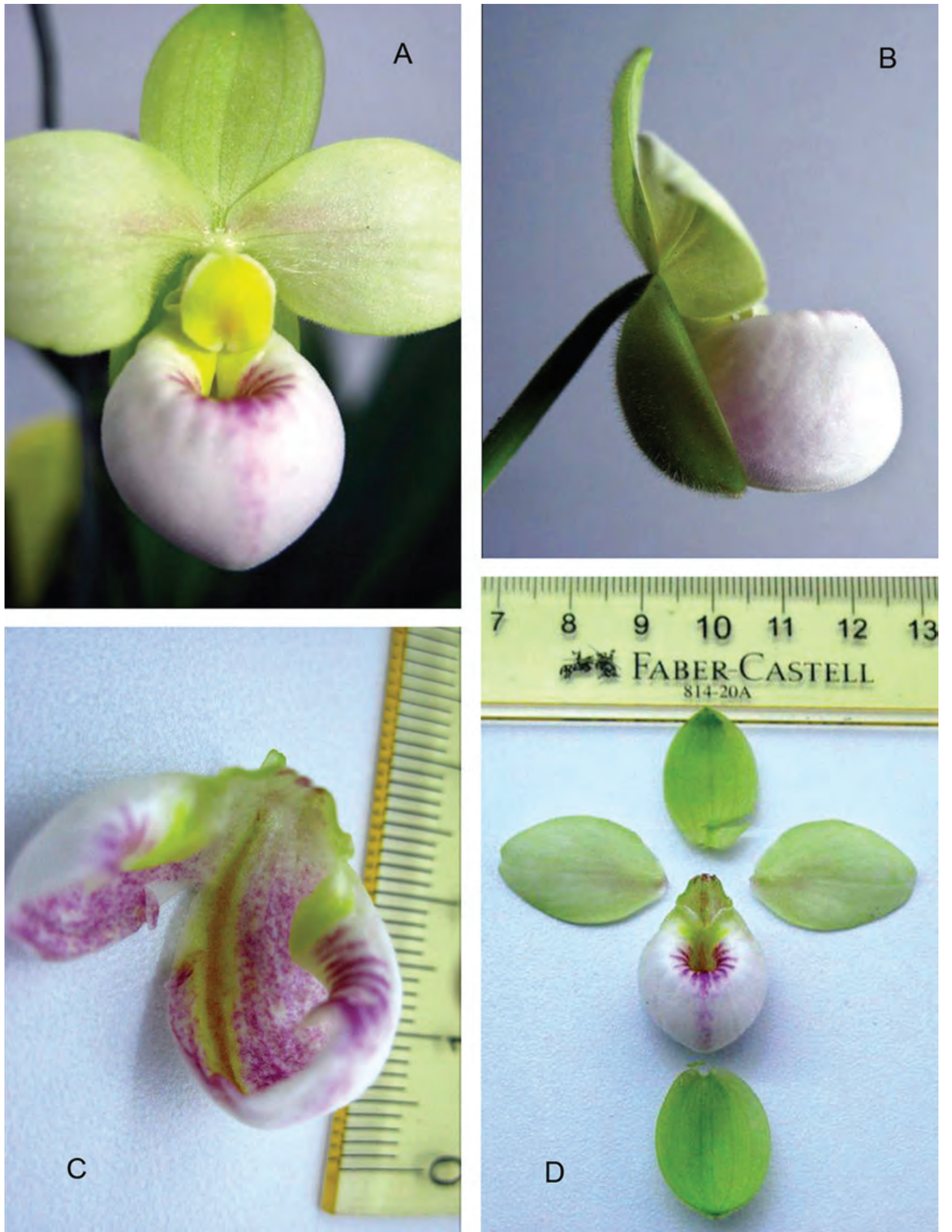

Figure 2. Phragmipedium manzurii W.E.Higgins \& P.Viveros. A. Flower, frontal view. B. Flower, lateral view. C. Dissected pouch. D. Dissected flower. Photos by D. A. Manzur. 


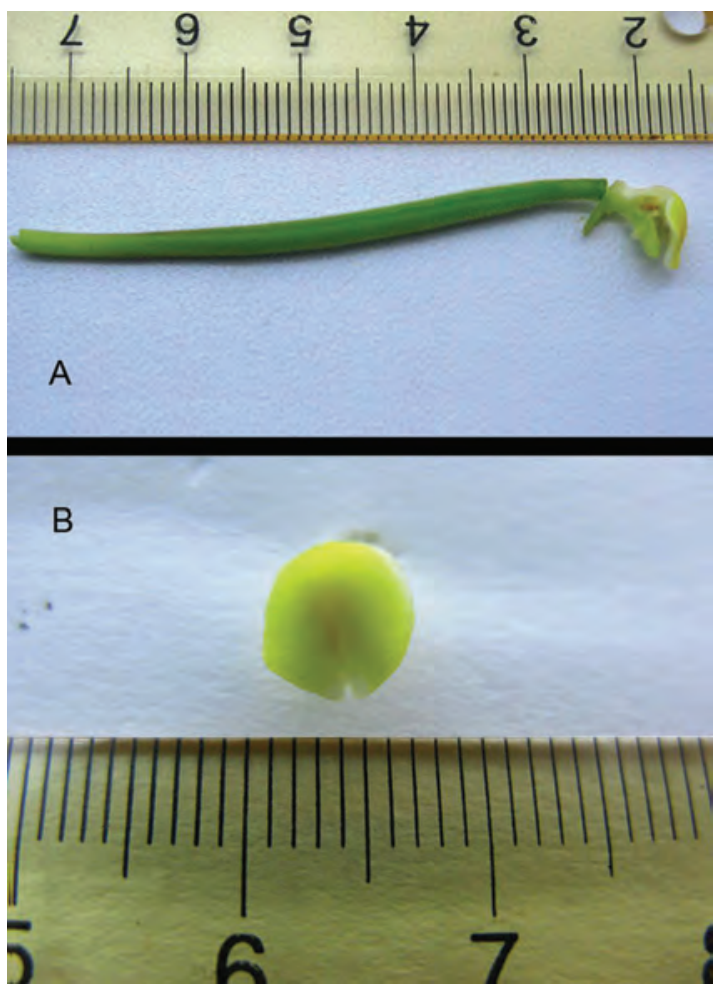

FIgURE 3. Phragmipedium manzurii W.E.Higgins \& P.Viveros. A. Side view of ovary. B. Front view of staminode. Photos by D. A. Manzur.

somewhat concave, pubescent on reverse; dorsal sepal elliptical, $2 \mathrm{~cm}$ long, 1 to $1.5 \mathrm{~cm}$ wide; synsepal 1.8 to $2 \mathrm{~cm}$ long, 1.4 to $1.7 \mathrm{~cm}$ wide. Petals white, flushed with pale violet, elliptical, slightly recurved, hirsute pubescent, 2.2 to $2.8 \mathrm{~cm}$ long, 1.1 to $2 \mathrm{~cm}$ wide. Lip white flushed pale violet, yellow-green at base, with violet markings, saccate with the apex turned up in front and the margin infolded, opening marked with short violet ridges, interior marked with violet spots, central yellow/violet lines on interior, tomentose pubescent, 1.8 to $2.4 \mathrm{~cm}$ long, 1 to $1.7 \mathrm{~cm}$ wide. Staminode green-yellow, round, raised center, notched on bottom margin, tomentose pubescent, 0.6 to $0.8 \mathrm{~cm}$ long, 0.6 to $0.8 \mathrm{~cm}$ wide.

Eтymology: Named for David Angel Manzur, a retired professor of the Facultad de Agronomía, Universidad de Caldas, Manizales, Colombia. Manzur has been doing field research, observing, collecting and growing orchids for 20 years, with special interest in

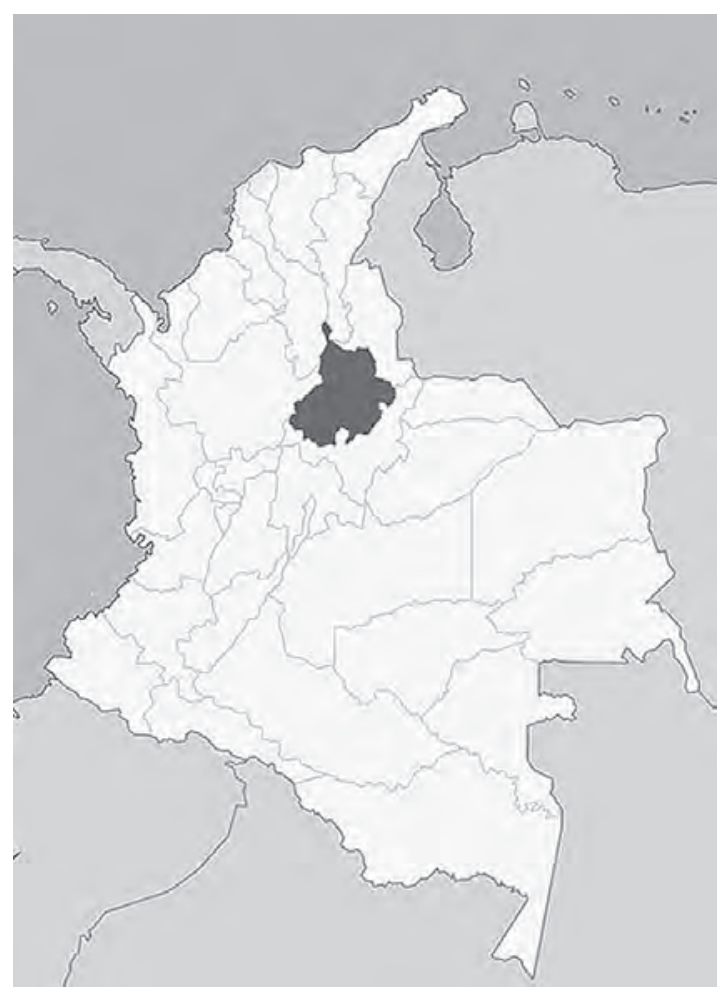

Figure 4. Department of Santander, Colombia.

Miltoniopsis vexillaria varieties and Phragmipedium. $\mathrm{He}$ is a member of the Risaralda Orchid Society and has received two American Orchid Society awards: Bollea coelestis David Manzur La Aldea FCC/AOS and Miltonia David Manzur La Aldea AM/AOS. Prior to this description, one species had been described in his name: Chodrorhyncha manzurii P.Ortiz. Professor Manzur has authored one orchid publication: Miltoniopsis vexillaria distribution and variation in Colombia [Orchids 74(1): 26-31. 2005].

Additional specimen seen: June 2008, D.A. Manzur 1507 (FAUC).

Distribution. Reported from the Department of Santander, Colombia (Fig. 4).

ACKNOWLEDGMENTS. The authors thank David Manzur and Leon Trujillo for bringing this species to the attention of the Orchid Identification Center and Phillip Cribb for revision of the Latin diagnosis. 